\title{
HOST MORTALITY, LETHAL PERIOD, TRANSMISSIBILITY, AND THRESHOLD DENSITY OF VERTICILLIUM LECANII - SCOTINOPHARA SP. MYCOSIS
}

\author{
F.X. Susilo ${ }^{1}$, Nyoman Mulyasari ${ }^{2}$, Rozali $^{3}$, and Sudi Pramono ${ }^{1}$
}

\begin{abstract}
Host mortality, lethal period, transmissibility, and threshold density of Verticillium lecanii - Scotinophara sp. mycosis. This study, conducted at Laboratory of Plant Protection Gading Rejo, Tanggamus-Lampung during March - October 2002, was aimed at determining the host mortality, lethal period, transmissibility, and threshold density of Verticillium lecanii Scotinophara sp. mycosis generated from cadaver exposure and conidial spray in potted rice plants. The cadaver exposure was implemented by inoculating various levels of inoculum to different levels of host population while the conidial spray was done by spraying $V$. lecanii starter suspension or suspension of homogenized Scotinophara sp. cadavers to the host. After incubation, newly formed cadavers (new infections) were collected. The host mortality was expressed as percentage of the host number by inoculation technique while the lethal (infection) period was averaged from overall data (grand average) or from data sorted by inoculation technique. Transmissibility was taken to be the significant regression slope between new infections and potential contact while threshold density value was taken as the ratio between the inverse value of lethal period (numerator) and transmissibility (denominator). Results showed that the host mortality after exposure to 2 cadavers was significantly lower (1.7\%) than that after exposures to $4-10$ cadavers or after conidial sprays (10 - 25\% range). The lethal period of the mycosis ranged from 5.2 to 15.8 days (no difference between inoculation techniques) while the disease transmissibility was 0.025 infection potential contact ${ }^{-1}$. The threshold density of the mycosis was 4.0 individuals of susceptible Scotinophara sp. rice plant ${ }^{-1}$. The fungus $V$. lecanii could be importance as a naturally-occurring biological control agent against Scotinophara sp.
\end{abstract}

Key words: Scotinophara sp., Verticillium lecanii, host mortality, lethal period, transmissibility, threshold density

\section{INTRODUCTION}

Verticillium lecanii - Scotinophara sp. mycosis is worth studying because of its practical or scientific importance. The host insect (Scotinophara sp., Hemiptera: Pentatomidae) often caused severe outbreak in the rice field, especially in Sumatra (Kalshoven, 1981). Both the adults and nymphs pierced and sucked the plant sap (mainly at the stem nodes) by using their stylets, resulting in half-filled and empty grains or the death of the rice plants and causing 35\% losses or more in some rice fields (Kalshoven, 1981; Rice Doctor, 2003). Meanwhile, the pathogen, i.e. Verticillium lecanii (Zimm.) Viegas (Hyphomycetes; Humber, 2005) (or known as its teleomorph Torrubiella confragosa Mains, Ascomycota: Hypocreales; Bischoff \& White, 2004) was then newly found to infect Scotinophara sp. in Yogyakarta area (NM was first informed about the infection by staff at Laboratory of Plant Protection Bantul - Yogyakarta in February 2002 and since she has successfully generated the mycosis at Laboratory of Plant Protection Gading Rejo - Lampung). There has been no, if any, published account on the mycosis to date reported from Sumatra.

Studies on insect mycosis have been mostly directed towards assessment of the potential (prospect) of the corresponding pathogen as a microbial insecticide (as implied in Burges \& Hussey, 1971 and in the majority of the accounts in Martono et al., 1993). The insecticidal activity has been commonly indicated by the host mortality, expressed in number of host deaths or percentage of the deaths relative to the total number of the tested host and presented in the form of dose-response illustrations, i.e. from simple diagrams to probit curves (Susilo, 1991). As an indicator of mycosis efficacy, however, the existing disease-induced mortality estimate seemed to have two limitations. First, its data analysis was based on bioassay on a fixed number of tested host, as such that the result (i.e. percentage of mortality) assumed only that number of host as the reference. It was therefore questionable whether the level of mortality commonly measured was consistent

\footnotetext{
${ }^{1}$ Lecturer at Plant Protection Department, Faculty of Agriculture, University of Lampung; Jl. Sumantri Brojonegoro, Bandar Lampung 35145

${ }^{2}$ Alumnus of Plant Protection Department, Faculty of Agriculture, University of Lampung

${ }^{3}$ Former Head, Laboratory of Plant Protection Gading Rejo-Tanggamus, Lampung (currently staff, UPTD Proteksi Tanaman, Lampung)
} 
(applicable) to various levels of host number (as would be expected to occur in the field, i.e. host population varied from place to place and from time to time). More importantly, the widely used doseresponse mortality analysis could not answer the frequently asked question related to the use of entomopathogen as biological agent for pest control, as follows - Can the biological agent of interest act as a density-dependent mortality factor against the target pest (Garcia et al., 1988)?

Second, the mortality data only measured what portion of host population affected (i.e. killed) by the disease. It did not measure what has happened (and how it happened) within that affected portion. The corresponding pathogen would look more promising only if it killed higher portion of the host, and vice versa. It did not indicate how fast the (portion of) host was killed; or if it did, as in the lethal time analysis (LT50), it still required higher killing ability (i.e. probit analysis would only be accurate if the pathogen induced more than 50\% mortality in the tested host population). In fact, it should be selfevident that shorter lethal time implied higher ability of the pathogen to kill the host (pathogenicity). Therefore the lethal time (period) was not a trivial indicator of mycosis efficacy.

Not less important is the study on disease transmissibility (Brown \& Hasibuan, 1995). Transmissibility measured the pathogen's ability to move successfully from the infected (and killed) host to a new host. This host-to-host spread allowed the pathogen to actively persist in the host population. It became clear that pathogenicity related to the host killing while transmissibility related to the spread of the pathogen. Pathogenicity decreased the disease prevalence through the host death and decay while transmissibility increased the prevalence through new infections (Susilo et al., 1993). The formal relationship between pathogenicity $(\mu)$ and transmissibility $(\rho)$ has been termed as the threshold density $\left(\mathrm{S}_{\mathrm{t}}{ }^{*}\right)$ (Brown, 1987; Equation 1). A threshold density was expressed as the population density of the host above which the disease prevalence could only increase and below which the disease prevalence could only decrease.

$\mathrm{S}_{\mathrm{t}}^{*}=\mu / \rho$

The main objective of this study was to determine host mortality, lethal period, transmissibility, and the threshold density of the
Verticillium lecanii - Scotinophara sp. mycosis. The study was expected to contribute to the scientific knowledge (insect pathology) and/or practical information (the black rice bug control).

\section{MATERIALS AND METHODS}

This study was initiated by preparing various handling arenas for the $V$. lecanii - Scotinophara sp. pathosystem, including rearing arenas, inoculation arenas, and incubation arenas. A handling arena basically consisted of a plastic cage suspended over soiled pot (mouth diameter $=13.5 \mathrm{~cm}$ ) with a rice plant (age one month; var. IR-64) grown within. Arena used for rearing (either susceptible insects or infective host) was designated as the rearing arena while one used for disease inoculation was designated as the inoculation arena and the other used for disease incubation was designated as the incubation arena.

Scotinophara sp. imagoes were collected for use as the susceptible or infective host during MarchApril 2002. The insects were field-collected alive using a light trap (100 watt-bulb) from the rice fields at the vicinity of Laboratory of Plant Protection Gading Rejo, Tanggamus - Lampung. The field condition were very dry and the rice plants were heavily attacked by the pest. The insects were then transferred and acclimated into green house condition in the rearing arenas. To facilitate adequate number of host, more of such arenas were set to rear Scotinophara sp. that have hatched from the laboratory - stock as well as manually field collected eggs, resulting in a total of 20 rearing arenas each inhabited by at least 100 individuals of Scotinophara sp. imagoes. Insects within ten rearing arenas (host cages) were then used as the susceptible host (susceptibles or $S_{t}$ sensu Brown, 1987) while those within the other (and separately placed) ten rearing arenas (inoculum cages) were used to generate disease inoculum (infecteds or $\mathrm{I}_{\mathrm{t}}$ sensu Brown, 1987).

Two sets of inoculation techniques were arranged. The first was aimed to determine the threshold density (including the pathogenicity) of $V$. lecaniiScotinophara sp. mycosis and the percentage of Scotinophara sp. mortality induced by $V$. lecanii infection. The second technique was aimed to determine the pathogenicity and the disease-induced mortality. The inoculum was generated by spraying $V$. lecanii suspension $\left(7 \times 10^{7}\right.$ conidia $\mathrm{ml}^{-1}$ of water, originated from Laboratory of Plant Protection Bantul, Yogyakarta) to Scotinophara sp. imagoes within the 
ten inoculum cages. The resulting Scotinophara sp. cadavers were transferred to an incubation arena, observed for disease signs for confirmation of $V$. lecanii infection, and used as inoculum $\left(\mathrm{I}_{\mathrm{t}}\right)$ for the inoculations.

The first inoculation technique (cadaver exposures) were set by placing various levels of inoculum (infecteds, $\mathrm{I}_{\mathrm{t}}$ ), i.e. 2, 4, 6, 8, or 10 Scotinophara sp. cadavers in the inoculation arenas harboring different levels of host population (susceptibles, $\mathrm{S}_{\mathrm{t}}$ ), i.e. 5, 10, 15, 20, or 25 individuals of Scotinophara sp. (taken from the host cages). Inoculation was done by pinning the infecteds to the base of the rice plants in the inoculation arenas where the susceptibles crowded. The inoculation arenas were observed daily for evidence of the host deaths shown by positive counts of new Scotinophara sp. cadavers. New cadavers were transferred to incubation arenas and observed for disease signs (infection by $V$. lecanii) (new infections). The dates of collection $\left(T_{i}\right)$ and the number of new infections $\left(M_{i}\right)$ were recorded. The major types of information that were resulted from this experiment were the lethal infection period (lethal period), the pathogenicity, and the relationship (slope) between the number of new infections and the potential contacts (the product of infecteds and susceptibles, i.e. $S_{t} I_{t}$ sensu Brown, 1987). The lethal period was taken to be its weighted mean $\left(\mathrm{T}=\sum \mathrm{M}_{\mathrm{i}} \mathrm{T}_{\mathrm{i}}\left(\sum \mathrm{M}_{\mathrm{i}}\right)^{-1}\right)$ while the slope was determined by regressing the number new infections (y-axis) with the potential contacts (x-axis). The inverse of the lethal period was taken to be the pathogenicity value while the slope was taken to be the transmissibility value. The ratio between the pathogenicity (numerator) and the transmissibility (denominator) was taken to be the threshold density (Brown, 1987; Susilo, 2000) of $V$. lecanii Scotinophara sp. Meanwhile, the percentage of $V$. lecanii-induced mortality $\left(\mathrm{P}_{1}\right)$ was determined using a simple formula of the (number of) new infections multiplied by 100 and divided by the number of susceptibles $(5,10,15,20$, or 25 individuals).

The second inoculation techniques were designated as the conidial spray. Starter suspension of V. lecanii $\left(7 \times 10^{7}\right.$ conidia $\mathrm{ml}^{-1}$ of water) (Spray 1$)$ or cadaver homogenate suspension $\left(0.3 \times 10^{7}\right.$ conidia ml ${ }^{-}$ ${ }^{1}$ of water) (Spray 2) was sprayed to 20 Scotinophara sp. imagoes within the inoculation arena (three replicates). The resulting Scotinophara sp. cadavers were transferred to an incubation arena and observed for disease signs. Scotinophara sp. cadavers confirmed as infected by $V$. lecanii were tallied daily for determination of the lethal infection period (and for that matter, the pathogenicity). The percentage of $V$. lecanii-induced mortality $\left(\mathrm{P}_{2}\right)$ was determined using the formula similar to the afore-mentioned one $\left(\mathrm{P}_{1}\right)$, except that the divisor was 20.

The cadaver exposure and the conidial spray inoculation techniques were done simultaneously in the same laboratory room, as such that both were considered as the treatments of the same experiment. The difference was that threshold density was measured only in the cadaver exposure while the other information (lethal infection period, pathogenicity, and percentage of $V$. lecanii - induced mortality) was measured in both sets of techniques. The later variables were compared among treatments, i.e. cadaver exposures (2, 4, 6, 8, or 10 infecteds), Spray 1 , and Spray 2 using a protected least significance difference test with $\alpha=0.05$ (for the percentage of $V$. lecanii - induced mortality) or using 0.95 a confidence interval (for the means of lethal period). Relationship between the disease-induced mortality and the number of susceptible Scotinophara sp. host in each cadaver exposure treatment was determined using Pearson product-moment linear correlation analysis ( $\mathrm{t}$ test; $\alpha=0.05$ ). Simple linear regression analysis followed any significant correlation ( $\mathrm{y}$-axis = disease-induced mortality, $\mathrm{x}$-axis $=$ the number of susceptible Scotinophara sp. host) (Snedecor \& Cochran, 1980). The later analysis was to observe whether $V$. lecanii could act as a density-dependent mortality factor against Scotinophara sp.

\section{RESULTS AND DISCUSSION}

Host Mortality. Subtle difference in the diseaseinduced mortality was detected. While cadaver exposures (4 - 10 cadavers) versus conidial sprays (Spray 1 and Spray 2) in general did not give different mortality responses, it was clear that exposing susceptible host to 2 cadavers resulted in less host mortality $(1.7 \%)$ as compared with host mortality resulted from exposures to $4-10$ cadavers or conidial sprays $(10-25 \%$ range, Table 1$)$. It was also clear that when 4 cadavers were used as inoculum, the disease-induce mortality correlated positively with the number of host (Table 2). The disease - induced 
Table 1. The means of disease-induced mortality of Scotinophara sp. treated with $V$. lecanii of various inoculation techniques

\begin{tabular}{lc}
\hline \multicolumn{1}{c}{ Inoculation technique } & Mortality (\%) $^{\ddagger}$ \\
\hline Cadaver exposure 1 (2 infecteds) & $1.7 \mathrm{a}$ \\
Cadaver exposure 2 (4 infecteds) & $10.0 \mathrm{~b}$ \\
Cadaver exposure 3 (6 infecteds) & $16.7 \mathrm{~b}$ \\
Cadaver exposure 4 (8 infecteds) & $16.7 \mathrm{~b}$ \\
Cadaver exposure 5 (10 infecteds) & $25.0 \mathrm{~b}$ \\
Conidial spray 1 (starter suspension) & $20.0 \mathrm{~b}$ \\
Conidial spray 2 (cadaver suspension) & $16.7 \mathrm{~b}$ \\
\hline
\end{tabular}

"Cadaver exposures = Inoculation Techniques \#1; Conidial sprays = Inoculation Techniques \#2

${ }^{\ddagger}$ Mean values followed by the same letter were not significantly different (protected LSD test, $\alpha=0.05$, test was done on arcsine $\sqrt{ } \%$ data).

Table 2. Pearson product-moment linear correlation between disease-induced mortality (\%) and the number of susceptible Scotinophara sp. host

\begin{tabular}{lc}
\hline Inoculation technique & Correlation coefficient \\
\hline Cadaver exposure 1 (2 infecteds) & $0.11^{\text {tn }}$ \\
Cadaver exposure 2 (4 infecteds) & $0.88^{* *}$ \\
Cadaver exposure 3 (6 infecteds) & $-0.22^{\text {tn }}$ \\
Cadaver exposure 4 (8 infecteds) & $0.46^{\text {tn }}$ \\
Cadaver exposure 5 (10 infecteds) & $0.27^{\text {tn }}$ \\
\hline
\end{tabular}

**)significantly different from zero (t test, $\alpha=0.01)$; ${ }^{\mathrm{tn}}$ ) not significantly different from zero

( $\mathrm{t}$ test, $\alpha=0.05$ ); test was done on arcsine $\sqrt{ } \%$ mortality data.

mortality increased in proportion as the host number increased (Figure 1). Addition of every individual host to the pathosystem was followed by an increase of $1.6 \%$ (back-transformed) in disease-induced mortality (slope significantly differed from zero, t test, $\alpha=0.01$ ) but the maximum host mortality was less than $50 \%$.

Lethal Period and Pathogenicity. From overall pooled data (cadaver exposures and conidial sprays combined), a total of 190 Scotinophara sp. cadavers were confirmed as infected by $V$. lecanii (new infections). Daily distributions of new infections were depicted in the scatter diagram of Figure 2. The calculated average $( \pm$ standard error) of the lethal (infection) period $(\mathrm{T})$ was $10.2( \pm 0.5)$ days (significantly different from zero, $\mathrm{t}$ test, $\alpha=0.05, \mathrm{n}=$ 190). The inverse value, i.e. the pathogenicity $\left(\mu=\mathrm{T}^{-}\right.$ $\left.{ }^{1}\right)$ was, therefore 0.10 ; which means that, on average, the $V$. lecanii - iI ' ected Scotinophara sp. imago was dying at a rate of 0.1 death day ${ }^{-1}$.
Table 3 indicates the lethal infection period (and pathogenicity) of Scotinophara sp. following inoculation of $V$. lecanii with various techniques. In general, cadaver exposures did not induce different lethal period (hence pathogenicity) as compared with conidial sprays. The lethal period due to cadaver exposure ( $2-10$ cadavers) was in the same range as those due to conidial sprays (5.2 - 15.8 days). As a corollary, the pathogenicity was also in the common range $\left(0.08-0.15\right.$ death day $\left.{ }^{-1}\right)$.

Transmissibility and Threshold Density. A linear relationship between the new infections and susceptible-infective potential contacts could be drawn from cadaver exposure data (Figure 3 ). The resulting regression slope, i.e. the transmissibility $(\rho)$, was 0.025 infection potential contact ${ }^{-1}$ (significantly different from zero, t-test, $\alpha=0.01$ ), which means that every potential contact between susceptible and infected host resulted in 0.025 actual infection to the host. In other words, the efficiency of the pathogen 


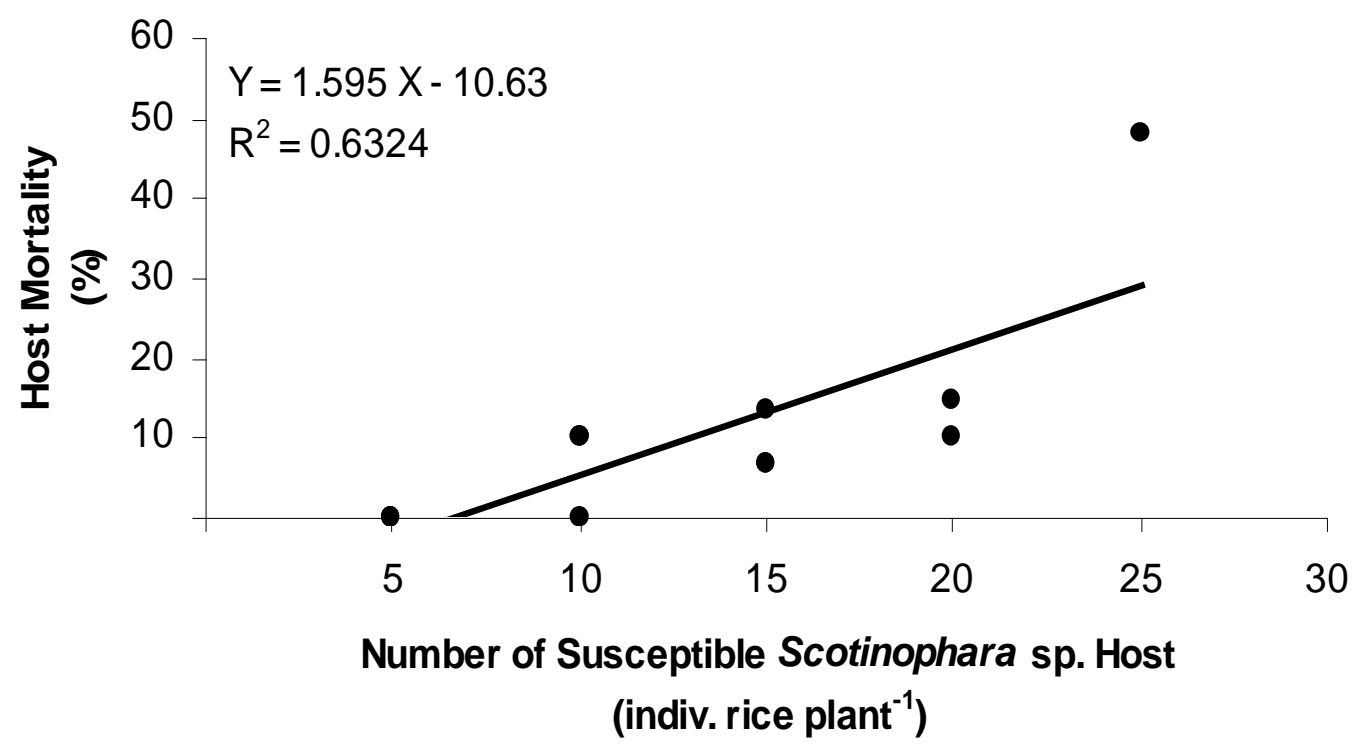

Figure 1. Relationship between $V$. lecanii-induced mortality and the number of Scotinophara sp. host (four $V$. lecanii-infected cadavers were used as inoculum).

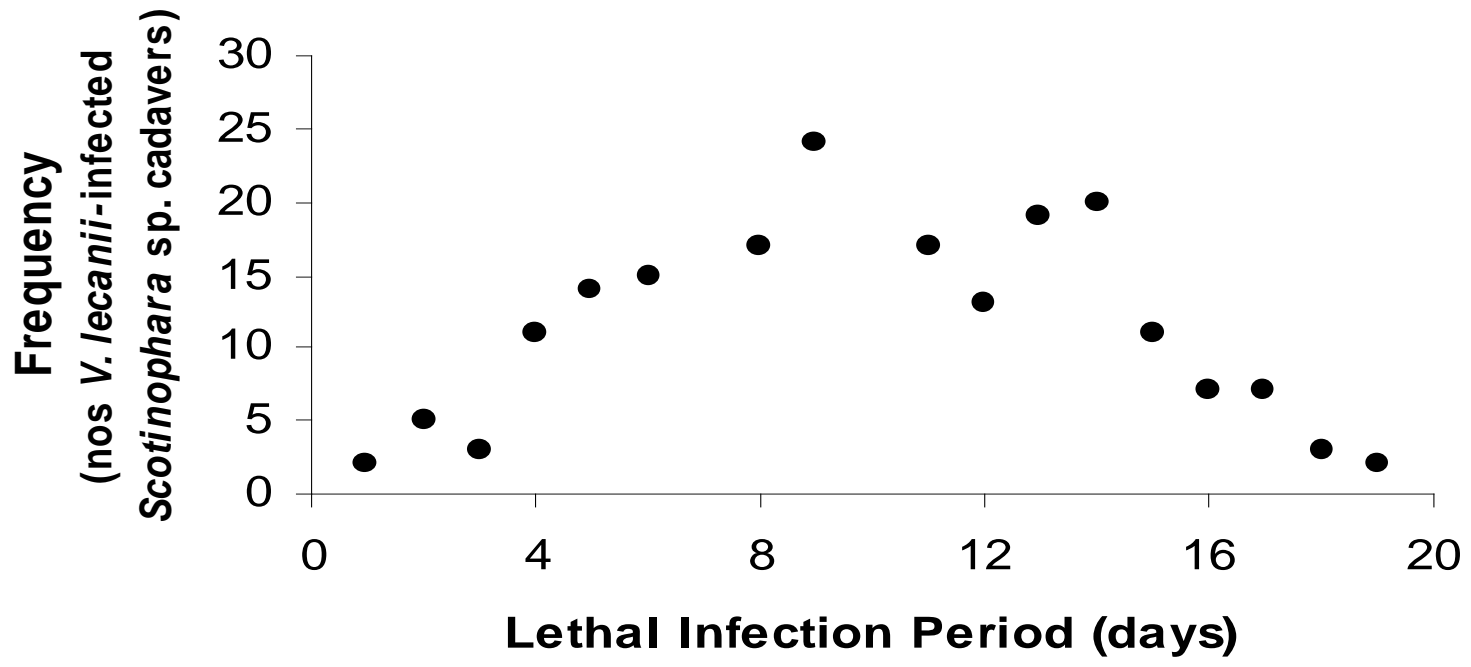

Figure 2. Daily distributions of the number of confirmed V. lecanii-Infected Scotinophara sp. cadavers (new infections). 
Table 3. The lethal infection period in the $V$. lecanii-Scotinophara sp. pathosystem with various inoculation techniques

\begin{tabular}{|c|c|c|c|c|c|}
\hline \multirow{2}{*}{ Inoculation technique } & \multicolumn{4}{|c|}{ Lethal infection period ${ }^{¥}$ (days) } & \multirow{2}{*}{$\begin{array}{c}\text { Pathogenicity }{ }^{\epsilon} \text { (death } \\
\text { day }^{-1} \text { ) }\end{array}$} \\
\hline & Lower & Mean & Upper & $\mathrm{n}^{\S}$ & \\
\hline Cadaver exposure 1 (2 infecteds) & 6.8 & 9.6 & 12.4 & 13 & 0.10 \\
\hline Cadaver exposure 2 (4 infecteds) & 5.2 & 6.6 & 8.0 & 24 & 0.15 \\
\hline Cadaver exposure 3 (6 infecteds) & 9.0 & 10.2 & 11.4 & 48 & 0.10 \\
\hline Cadaver exposure 4 (8 infecteds) & 9.4 & 10.8 & 12.2 & 30 & 0.09 \\
\hline Cadaver exposure 5 (10 infecteds) & 10.2 & 11.4 & 12.6 & 53 & 0.09 \\
\hline Conidial spray 1 ( starter suspension) & 8.8 & 12.3 & 15.8 & 10 & 0.08 \\
\hline Conidial spray 2 (cadaver suspension) & 8.1 & 9.5 & 10.9 & 12 & 0.11 \\
\hline Overall $^{£}$ & 9.2 & 10.2 & 11.2 & 190 & 0.10 \\
\hline
\end{tabular}

"Cadaver exposures = Inoculation Techniques \#1; Conidial sprays = Inoculation Techniques \#2.

${ }^{\sharp}$ Based on 0.95 confidence interval $(\alpha=0.05)$ of the corresponding means.

${ }^{€}$ Inverse of the (mean) lethal infection period (sensu Brown, 1987).

${ }^{\varepsilon}$ Pooled from Inoculation Techniques \# 1 and \# 2 data.

${ }^{\S} \mathrm{New}$ infections, i.e. number of cofirmed V. lecanii - infected cadavers (infecteds) each resulted from 60 susceptibles.

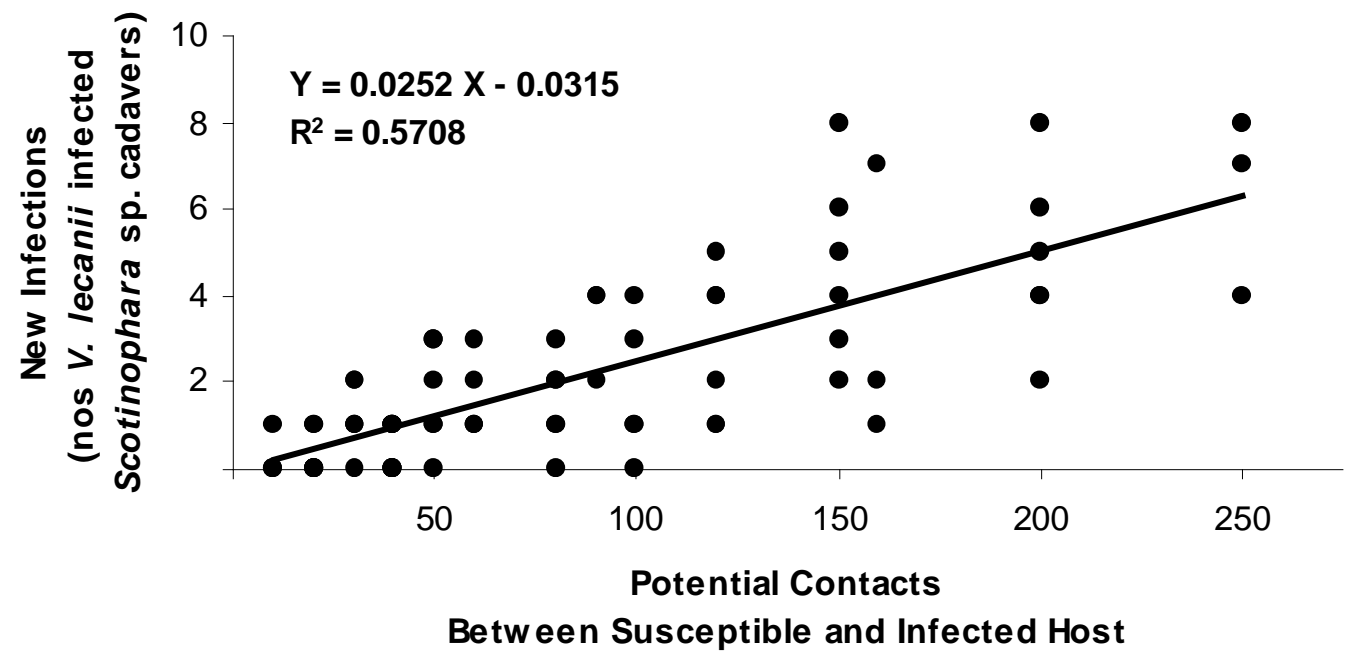

Figure 3. Linear relationship between $V$. lecanii infections and potential contacts of susceptible and infected Scotinophara sp. Host. 
(V. lecanii) to induce disease to the host insect (Scotinophara sp.) population was $2.5 \%$. Thus, the threshold density was 4.0 individuals of susceptible Scotinophara sp. rice plant ${ }^{-1}\left(\mathrm{~S}_{\mathrm{t}}{ }^{*}=\mu \rho^{-1}=0.10 / 0.025\right.$ $=4.0$ ).

Discussion. In a pest control situation (i.e. microbial control of insects, Burges \& Hussey, 1971), a pathogen could be used either as a biological (control) agent (natural enemy) or as an (active ingredient of) insecticide. A good natural enemy should have two characteristics, i.e. self-sustaining in the environment (i.e. in the host population) and able to act as a density-dependent mortality factor against the target pest (Garcia et al., 1988). Pathogen could be introduced via inoculative releases (Tanada \& Kaya, 1993), and with adequate transmission produced progeny which persisted and spread in the pest population (self-sustenance) as such that long-term control was achieved (density-dependent). Meanwhile, other pathogen might survive in the environment without an effective mechanism of transmission (Tanada \& Kaya, 1993). Periodic reintroduction of the pathogen would be needed to grant its existence in the environment and adequate pathogenicity would be a must if a significant level of pest control was desired. In other words, trait to characterize a pathogen for use as biological agent was transmissibility while that for use as insecticide was pathogenicity (Susilo, 2000).

What did high threshold density indicate? The purpose of using pathogen against its host pest was to achieve an epizootic level of disease prevalence as such that the surviving host could be economically negligible. As indicated by Waltman (1974) and Brown (1987), the pest population density had to surpass the threshold density for epizootic to occur. But increasing pest density for that purpose might not be possible because of a serious reason. The ultimate goal of any pest control effort was to suppress (decrease) the pest population to minimize crop yield loss, so any effort to increase the pest population (for instance, to a level above the threshold density and even with the hope of achieving epizootics so as to reduce surviving pest population) would be illogical, absurd, and counter productive. On the other hand, to let the pest population lower than the threshold density would drag the disease prevalence down into enzootic level (assuming some transmissibility existed) or even into (local) crash. In short, a pathosystem with high threshold density signaled unsustainability of the corresponding pathogen and thus would not be feasible in terms of conventional biological control (pathogen as natural enemy). What, then, would be more reasonable approach to pest control in a pathosystem with high threshold density? Microbial pesticide. A good microbial pesticide was characterized by its high efficacy (host killing ability, pathogenicity), i.e. it could infect and kill host fast enough (short lethal infection period). Transmissibility would not be a concern in here because the pesticide (pathogen) might be introduced repeatedly so as to achieve high level of disease prevalence (epizootic).

Can the use of $V$. lecanii induce disease to epizootic level in Scotinophara sp. population? If so, how could that be achieved, i.e. using the pathogen as biological control agent or as microbial insecticide? How could the threshold density of $V$. lecanii Scotinophara sp. mycosis be used to elucidate the case, at least as compared with other mycoses whose threshold densities have been studied so far?

The threshold density $\left(\mathrm{S}_{\mathrm{t}}^{*}\right)$ of $V$. lecaniiScotinophara sp. (VLSS) mycosis was 4.0. This value was higher than that of other mycoses previously studied including Beauveria bassiana - Leptocorisa acuta (BBLA) $\left(\mathrm{S}_{\mathrm{t}}{ }^{*}=1.4\right.$ plant $^{-1}$, Faidzal et al., 1996), Metarhizium anisopliae-Nilaparvata lugens (MANL) $\left(\mathrm{S}_{\mathrm{t}}{ }^{*}=2.2\right.$ plant $^{-1}$, Dewi et al., 1998), M. anisopliaeNezara viridula (MANV) $\left(\mathrm{S}_{\mathrm{t}}{ }^{*}=2.3\right.$ plant $^{-1}$, Ismanto et al., 1999), and M. anisopliae - Aphis glycines (MAAG) $\left(\mathrm{S}_{\mathrm{t}}^{*}=1.6\right.$ plant $^{-1}$, Arianti, 2000). The threshold density value of 4.0 plant $^{-1}$ meant that; if the susceptible host (i.e. healthy Scotinophara sp.) in the mycosis (VLSS) was lower than 4.0 rice plant $^{-1}$, then the disease prevalence would decrease (toward enzootic level or crash); if the host reached a population higher than 4.0 , then the number of infected host would increase. In other words, to start epizootic episode, $V$. lecanii (in VLSS mycosis) would require higher host population than $B$. bassiana (in BBLA mycosis) or $M$. anisopliae (in MANL, MANV or MAAG mycoses).

Compared with the afore-mentioned four mycoses, the VLSS mycosis was inferior in terms of pathogenicity. The pathogenicity of the former ranged from 0.12 to 0.19 death $^{-1 a{ }^{-1}}$ (Susilo, 2000) while that of the later was 0.10 death day $^{-1}$ (or lethal period mean of 10.1 days as in Figure 2, with 5.2 - 15.8 day range as in Table 3). That would indicate that $V$. lecanii has lower potential to be used as microbial insecticide against Scotinophara sp. as compared with 
B. bassiana against Leptocorisa sp. or M. anisopliae against Nilaparvata sp., Nezara sp., and Aphis sp.

In terms of transmissibility, however, $V$. lecanii surpassed $B$. bassiana. The transmissibility of $V$. lecanii (in VLSS) was lower (2.5\%, Figure 3) than that of $M$. anisopliae (in MANL, MANV, and MAAG) (5.5 - 11.5\% range) but higher than that of B. bassiana (in BBLA pathosystem) (1.5\%) (Susilo, 2000). Thus, in spite of its inferiority to M. anisopliae, the potential of $V$. lecanii as biological control agent against Scotinophara sp. was higher than that of $B$. bassiana against Leptocorisa sp.

Was there other indication, if any, of the biological control potential of $V$. lecanii? As indicated before, one of indicators for considering a natural enemy a good biological control agent was its ability to act as a density dependent factor against the target pest (Garcia et al.,1988). The natural enemy should be able to destroy a larger proportion of the pest population as the density of the pest increased (DeBach, 1974; DeBach \& Rosen, 1991). Figure 1 shows the proportional increase (i.e. in terms of percentage) in $V$. lecanii - induced mortality of Scotinophara sp. as the density of the host population increased. Could that be a signal for the densitydependent characteristic of $V$. lecanii against Scotinophara sp? Curiously enough, however, the density-dependent phenomenon was only detectable when the $V$. lecanii inoculum was 4 cadavers (infecteds) (Table 2). One could argue whether a kind of inoculum "threshold" was plausible to explain the phenomenon. Two infecteds (below the "threshold') might have been too small inoculum to induce adequate infection (ca. one fifth mortality of that induced by 4 infecteds, Table 1) to initiate a densitydependent process in the pathosystem. But inoculum number of more than 4 infecteds (above the "threshold") was not capable of promoting density dependent phenomenon either. Even when the density dependent phenomenon was detectable (i.e. induced by the inoculum number of 4) the highest mortality could not reach $50 \%$ level.

\section{CONCLUSIONS}

Conclusions that could be drawn from this study on V. lecanii - Scotinophara sp. mycosis are as follow:
The host mortality after exposure to 2 cadavers was significantly lower (1.7\%) than that after exposures to $4-10$ cadavers or after conidial sprays (10 - 25\% range). The lethal period of the mycosis ranged from 5.2 to 15.8 days (no difference between cadaver exposure and conidial spray techniques). The disease transmissibility was 0.025 infection potential contact $^{-1}$. The threshold density of the mycosis was 4.0 (individuals of susceptible Scotinophara sp. rice plant $\left.^{-1}\right)$.

The fungus $V$. lecanii might not as good candidate for a microbial insecticide because of its relatively low pathogenicity and low disease-induced mortality against Scotinaphara sp. However, the significant transmissibility and density-dependence indicated its importance as a naturally-occurring biological control agent against the host insect.

\section{ACKNOWLEDGMENT}

The authors thank Mr. Maman, Mr. Riyanto, Mr. Mustaqim, Mr. Bulkini, and other staff of Laboratory of Plant Protection Gading Rejo, Tanggamus for their assistance in the field as well as laboratory work.

\section{REFERENCES}

Arianti, M.P.D., F.X. Susilo, \& Indriyati. 2000. Disease transmission and density dependence effect of Metarhizium anisopliae inoculum on the soybean aphid (Aphis glycines). J. Pen. Pengb. Wil. Lahan Kering 22 (1): 21 - 27.

Bischoff, J.F. \& J.F. White Jr. 2004. Torrubiella piperis sp. nov. (Clavicipitaceae, Hypocreales), a new teleomorph of the Lecanicillium complex. Studies in Mycology 50: 89 - 94 .

Brown, G.C. 1987. Modeling. Pages 43 - 68 in: Fuxa, J.R. \& Y. Tanada, eds. Epizootiology of Insect Diseases. John Wiley and Sons, New York.

Brown, G.C. \& R. Hasibuan. 1995. Conidial discharge and transmission efficiency of Neozygites floridana, an entomopathogenic fungus infecting two-spotted spider mites under laboratory conditions. J. Invertebr. Pathol. 65: $10-16$. 
Burges, H.D. \& N.W. Hussey. 1971. Microbial Control of Insects and Mites. Academic Press, New York.

DeBach, P. 1974. Biological Control by Natural Enemies. Cambridge Univ. Press, London.

DeBach, P. \& D. Rosen. 1991. Biological Control by Natural Enemies. $2^{\text {nd }}$ ed. Cambridge Univ. Press, New York.

Dewi, M., F.X. Susilo, \& A.M. Hariri. 1998. Daya infeksi, efisiensi penularan, dan periode letal penyakit muskardin hijau (Metarhizium anisopliae) pada wereng coklat (Nilaparvata lugens). J. Penel. Pertanian 9: 156 - 166.

Faidzal, M., F.X. Susilo, \& L. Wibowo. 1996. Penentuan kepadatan ambang penyakit Beauveria bassiana - Leptocorisa acuta di laboratorium. J. Penel. Pertanian 8: 31 - 39.

Garcia, R., L.E. Caltagirone, \& A.P. Gutierrez. 1988. Roundtable: Comments on a redefinition of biological control. Bio Science 38 (10): 692 694.

Humber, R. A. 2005. Important note: revised taxonomy for Verticillium species affecting invertebrates.

http://www.ppru.cornell.edu/Mycology/catalo gs/vert_tax.doc. Browsed on 30 August, 2005.

Ismanto, A.N., F.X. Susilo, \& Indriyati. 1999. Potensi kontak antara inokulum dan inang menentukan efisiensi penularan penyakit muskardin hijau pada kepik hijau kedelai. $J$. Pengb. Wil. L. Kering 24: 28 - 36.

Kalshoven, L.G.E. 1981. The Pests of Crops in Indonesia. Ichtiar Baru - Van Hoeve, Jakarta.
Martono, E., E. Mahrub, N.S. Putra, Y. Trisetyawati. 1993. Prosiding makalah symposium patologi serangga I. PEI Cabang Yogyakarta, Fakultas Pertanian UGM, dan Program Nasional PHT/BAPPENAS, Yogyakarta.

Rice Doctor. 2003. Black bug. http: // www. knowledgebank.irri.org/riceDoctor_MX/Fact _Sheet/Pests/Black_Bug.htm\#When. Browsed on 30 August 2005.

Snedecor, G.W. \& W.G. Cochran. 1980. Statistical Methods. $7^{\text {th }}$ ed. The Iowa State Univ. Press., Ames.

Susilo, F.X. 1991. Epizootiological studies on Neozigytes floridana Weiser \& Muma (Entomophthorales:Neozygitaceae) infectious to the two-spotted spider mite, Tetranychus urticae Koch (Acari: Tetranychidae). Ph.D. dissertation. University of Kentucky, Lexington.

Susilo, F.X. 2000. Understanding the concept of threshold density of insect diseases in the frame work of epizootiology. Indon. J. Plant Protection 6 (2): 65 - 74.

Susilo, F.X., R. Hasibuan, G.L. Nordin, \& G.C. Brown. 1993. The concept of threshold density in insect pathology: a theoretical and experimental study on Tetranychus Neozygites mycosis. Pages $29-36$ in: Martono, E., E. Mahrub, N.S. Putra, \& Y. Trisetyawati, eds. Prosiding Makalah Simposium Patologi Serangga I. PEI Cabang Yogyakarta, Fakultas Pertanian UGM, Pronas PHT BAPPENAS, Yogyakarta.

Tanada, Y. \& H.K. Kaya. 1993. Insect Pathology. Academic Press, San Diego.

Waltman, P. 1974. Deterministic threshold models in the theory of epidemics. In: Levin, S., ed. Lecture Notes in Biomathematics. Springer Verlag, New York. 